\title{
READ ALOUD: AN LITERACY ACTIVITY IN ELEMENTARY SCHOOL
}

\author{
Nunuy Nurkaeti ${ }^{1}$, Sani Aryanto ${ }^{3}$, Yosi Gumala ${ }^{4}$ \\ ${ }^{1}$ Elementary School Teacher Education Program, Universitas Bhayangkara Jakarta Raya \\ ${ }^{2}$ Elementary School Teacher Education Program, Universitas Bhayangkara Jakarta Raya \\ ${ }^{3}$ Elementary School Teacher Education Program, Universitas Bhayangkara Jakarta Raya \\ 1 nunuy.nurkaeti@dsn.ubharajaya.ac.id, \\ 2 sani.aryanto@dsn.ubharajaya.ac.id, ${ }^{3}$ yosi.gumala@dsn.ubharajaya.ac.id
}

\begin{abstract}
Reading literacy is the main key on develop knowledge. Reading literacy in elementary schools was developed through the implementation of the school literacy movement. The literacy activities are carried out as evidence of the implementation of the school literacy movement. This study aims to describe the implementation of reading literacy activity and read aloud in elementary schools. The research method used was descriptive qualitative through data collection based on a questionnaire and documentation study at ten elementary schools in Majalengka. The results show that literacy activities have been implemented in primary schools, although they have not been routinely carried out. Reading literacy methods used include read aloud, review, alphabetical methods, and reading comprehension. There are schools that have used read aloud as an effort to increase the reading literacy of elementary school students. Generally teachers in schools do not yet know the read aloud and its implementation. Training is needed for teachers to developing literacy activities in primary schools, so that could optimizing literacy activities through the use of various reading strategies.
\end{abstract}

Keywords: Read Aloud, Literacy Activity, School Literacy Movement.

\begin{abstract}
Abstrak
Literasi membaca merupakan kunci utama dalam memperoleh pengetahuan. Literasi membaca di sekolah dasar dikembangkan melalui pelaksanaan gerakan literasi sekolah . Berbagai kegiatan literasi dilakukan sebagai bukti pelaksanaan gerakan literasi sekolah. Penelitian ini bertujuan untuk mengetahui pelaksanaan kegiatan literasi membaca dan read aloud di sekolah dasar. Metode penelitian yang digunakan adalah kualitatif deskriptif melalui pengumpulan data berdasarkan angket dan studi dokumentasi di sepuluh sekolah dasar di Majalengka. Hasilnya menunjukkan kegiatan literasi telah diimplementasikan di sekolah dasar walaupun belum secara rutin dilakukan. Metode literasi membaca yang digunakan meliputi read aloud, review, metode abjad, dan membaca pemahaman. Ada sekolah yang sudah menggunakan read aloud sebagai upaya meningkatkan literasi membaca siswa sekolah dasar. Umumnya guru di sekolah belum mengetahui read aloud dan pelaksanaanya. Diperlukan pelatihan bagi guru dalam mengembangkan kegiatan literasi di sekolah dasar agar dapat mengoptimalkan kegiatan literasi melalui penggunaan berbagai startegi membaca.
\end{abstract}

Kata Kunci: Membacakan Nyaring, Kegiatan Literasi, Gerakan Literasi Sekolah

\section{INTRODUCTION}

Literacy is an important component to realizing a nation that is able to compete globally. The quality of a nation is determined by the literacy of its human resources, especially reading literacy. According to Irianto \& Febrianti (2017) the way to master literacy is to instill reading habits. Reading is the basis for mastering all of knowledge. The key to get the information and knowledge is to have good reading literacy. 
Reading literacy is a fundamental thing that must be mastered by elementary school students. It is as a key to gaining knowledge. However, the conditions of the field indicate a lack of student interest in reading, which is has implications for lack of reading literacy for students. The results of research conducted by the Organization for Economic Co-operation and Development [OECD], 2016 through the Program for International Student Assessment (PISA) showed the reading ability of Indonesian students that aged 15 years was ranked 64th with a score of 397, which is the score was lower than the OECD average score is 496 . Correspondingly Rosidi (2008) mentions that Indonesian children read 27 pages of books per year or equal to 1 page in 15 days. They are encourages to develop of reading activities not only in subjects but in specific programs.

The School Literacy Movement Program, also known as GLS, is a literacy program in primary and secondary education. GLS has been implemented since 2016. The implementation is carried out in stages starting from habituation, development, and learning (Faizah, Sufyadi, Anggraini, Waluyo, Dewayani, Muldian, \& Roosaria, 2016).

GLS activities that take place in elementary schools are reading non-subject books as 15 minutes before learning begins, read aloud, shared reading, guided reading, joint reading, independent reading, and specifically in the learning phase intensively developed reading and writing abilities. In addition, the school also strives to create a literal environment through reading corners in the classroom and around the school environment. This is done to support the aims of GLS program, especially to develop student reading interest.

Activities in the GLS are recommended starting from the stages of habituation, development, and learning both of the low and high grade, one of which is the read aloud method (Faizah, et. Al., 2016). Read aloud is the most effective reading method for children that can condition a child's brain so that it can build knowledge, introduce new vocabulary, and associate reading activities as a fun activity. There are several benefits of read aloud, namely: 1) helps more optimal brain development; 2) introduce and practice listening skills; 3) increase the vocabulary heard; 4) practice attention span and remembering; 5) teach words that are rarely used everyday; 6) teach the meaning of words; 7) introducing the concept of print and writing media; 8) introduce images and illustrations; 9) able to calm down; 10) stimulates the imagination and other senses; and 11) introducing children to books and learning media (Setiawan, 2017). 
Based on the description above, read aloud is one of the recommended reading methods in GLS at primary schools. It could given that the benefits and characteristics of read aloud are suitable for elementary school students. This can be seen from the benefits of read aloud which is in line with the language skills of elementary school students. The most important thing is to build an attitude of reading fondness. However, have the reading literacy activity and read aloud been implemented better in elementary schools? Therefore, this descriptive qualitative research was carried out to see the implementation of literacy activities in primary schools and the use of the read aloud method in developing reading literacy of elementary school students.

\section{METHOD}

The method of this study is qualitative research to describe the implementation of literacy activity and read aloud in developing literacy activity in elementary school. Data was obtained by questionnaire and study documentation. The questionnaire contained ten questions about the implementation of GLS, the methods used in GLS as an effort to improve literacy reading, and the teacher knowledge about read aloud and its implementation. Furthermore, used analysis of data questionnaire and study documentation to answer the research questions. This research was conduted on ten elementary schools in Majalengka district.

\section{RESULTS AND DISCUSSION}

\section{Results}

Data analysis was performed on the results of the questionnaire by focusing on indicators arranged in the questionnaire. The indicators are implementing GLS activities in schools, using special methods to improve reading literacy activities, and teacher knowledge of read aloud and its implementation. The result of the data analysis questionnaire are combined with the data of documentation study. This is done to focus the description to answering research questions. The analysis of the results of the questionnaire can be seen in Table 1 below.

Table 1. Analysis of Questionnaire Results Data

\begin{tabular}{|c|c|c|}
\hline No & Indicators & $\begin{array}{ll} & \text { Analysis } \\
\end{array}$ \\
\hline 1. & $\begin{array}{ll}\text { Conducting } & \text { GLS } \\
\text { activities at school. } & \end{array}$ & $\begin{array}{l}\text { - All of schools have implemented GLS activities. } \\
\text { - As many as } 50 \% \text { of schools have not been regularly conducting GLS } \\
\text { - There are schools that scheduled and some are not scheduled the GLS } \\
\text { activities. There are } 40 \% \text { of schools that conducting literacy activities } \\
\text { once a week, } 10 \% \text { of schools conducting literacy activities twice a week, } \\
10 \% \text { of schools that conducting literacy activities } 3 \text { times a week, } 20 \% \\
\text { of schools that conducting literacy activities in learning but are not } \\
\text { routine, and } 20 \% \text { do not schedule literacy activities so they are not } \\
\text { necessarily implemented. } \\
\text { - There are many form of reading literacy activities that conducting at } \\
\text { school including the specific reading activities every time at } 13.00- \\
14.00 \text { WIB, reading activities in the morning before learning begins, } \\
\text { reading in the free time, taking students to read to the library, guiding }\end{array}$ \\
\hline
\end{tabular}




\begin{tabular}{|c|c|c|}
\hline No & Indicators & Analysis \\
\hline & & $\begin{array}{l}\text { individual students who have not been able to read, and give } \\
\text { assignments so students get information by reading. }\end{array}$ \\
\hline 2. & $\begin{array}{l}\text { Using specific methods to } \\
\text { improve reading literacy } \\
\text { activities. }\end{array}$ & $\begin{array}{l}\text { - Some schools have used specific methods in reading literacy activities. } \\
\text { They are read aloud, review, the alphabetical method for students who } \\
\text { have not been able to read, and reading comprehension for students who } \\
\text { have been able to read. As many as } 50 \% \text { of schools have not used } \\
\text { specific methods in reading literacy activities } \\
\text { - All respondents from the study sample said that they had never } \\
\text { participated in training activities as an effort to increase reading literacy } \\
\text { activities in elementary schools } \\
\text { - All respondents said there was a need for training activities for teachers } \\
\text { to develop reading literacy activities. Needs to do create literacy } \\
\text { activities well, increase teacher insight, improve teacher competence to } \\
\text { develop reading literacy strategies, and provide motivation for teachers } \\
\text { in creating optimal literacy activities. } \\
\text { - Activities that can improve the reading literacy of elementary students } \\
\text { are reading } 15 \text { minutes before learning, providing varied reading books } \\
\text { in the classroom and school environment, read aloud, reading } \\
\text { comprehension, story telling, writing stories, making products/works } \\
\text { from reading results, visiting library, and retell the contents of reading. }\end{array}$ \\
\hline 3. & $\begin{array}{l}\text { Teacher's knowledge of } \\
\text { read aloud and its } \\
\text { implementation. }\end{array}$ & $\begin{array}{l}\text { - Half }(50 \%) \text { of respondents did not know about the methods of } \\
\text { reading read aloud. } \\
\text { - As many as } 60 \% \text { of respondents said that read aloud could be } \\
\text { used to improve students' literacy reading. }\end{array}$ \\
\hline
\end{tabular}

\section{Discussion}

Literacy activities on the GLS program in primary schools are carried out in gradually. The results showed that all schools had implemented the GLS program. This is in line with the mandate of the government as stipulated in Peraturan Menteri Pendidikan dan Kebudayaan No. 23 of 2015 that GLS activities are implemented as an effort to foster student character and reading interest. However, the implementation has not been routinely done in schools. This is indicated by $40 \%$ of schools that do not schedule literacy activities in their schools. This shows the need for assistance in the implementation of GLS. Komalasari, Wibowo, \& Anggraini (2018) mentioned that GLS assistance involving schools and teachers needs to be done in increasing students' interest in reading. Ideally literacy activities are scheduled regularly and consistently. According to Teguh (2017) that the strategy for carrying out literacy activities can be done on a daily, weekly, monthly, and semesterly.

Implementation reading literacy activities that conducted by schools, be adapted with schools's and student's needs. This is line with research of Komalasari, Wibowo, \& Anggraini (2018) that the literacy programs have to made accordance with school conditions. The analysis shows that schools integrate literacy activities in learning. The activity consists of assignments in obtaining various information through reading activities. In addition, there is also a literacy program that supports students' reading skills, by providing special assistance to students who 
have not been able to read and reading activities for students who are already proficient in reading.

GLS activities have to increase the minimum reading literacy of students, so appropriate methods have to be used. The analysis shows that there are several schools that have used specific methods to improve student literacy. The methods that used include read aloud, review, alphabetical methods, and reading comprehension. As many as 50\% of respondent schools have not used specific methods in implementing literacy reading. So there is a need for training efforts for teachers to develop literacy programs thac could give improve literacy in elementary schools. Respondents (teachers) suggest that they need training to improve teacher competency, so that they can develop and improve literacy activities in their schools. This is in line with research recommendations by Komalasari, Wibowo, \& Angggraini (2018) and Suryono, Harsiati, \& Wulandari (2017) that have need of mentoring activities for schools and teachers, so that teachers are able to choose a variety of reading activities.

Tantri \& Dewantara (2017) explained that literacy culture programs could be done by reading 15 minutes before learning, organizing school and class libraries, creating reading corners and text-rich environments, and Saturday literacy activities can effectively increase student reading interest. This is in line with the results of study that could be improve reading literacy are expressed by the arranging of the literate reading of school environment, doing structured reading activities, and visiting the library to foster the interest reading of student, and read aloud activities.

Read aloud activities have not been fully implemented in schools. This was proven based on the results of the questionnaire that $50 \%$ did not know about the read aloud reading method. This is contrary to the activities suggested in GLS that the implementation of the recommended reading activities is read aloud (Faizah, et. Al., 2016). Apart from the context of the teacher's knowledge of read aloud, as many as $60 \%$ of teachers said that read aloud might be used to increasing students' literacy reading. Huda, Kartanegara, \& Zakaria (2015) mentioned that read aloud contributes to the development of students' skills for independent learning and understanding of knowledge. Read aloud not only develop students' reading skills, but also encourage students to more quickly understand of the knowledge that are learned.

Based on the results of the questionnaire obtained that there is one school that has implemented read aloud in reading literacy activities in schools. The activity is conducting before learning begins and when there is free time. Besides that, it is also done on activity GLS that are scheduled, which is twice a week. The read aloud activity is conducted with the student 
or teacher reading the story in front the class and the others are listening. During reading activities, there are interactions between those who read stories and also the audience. At the end, conclusions were made about the stories that were read, and conveyed the message of the story to build character. As the goal of GLS, one of which is to develop character. Thus, read aloud is very appropriate to be used in developing students' literacy reading, especially in primary schools.

\section{CONCLUSION}

Reading literacy activities through GLS have been implemented in primary schools, but have not been conducted routinely. Reading literacy activities are conducted by using various methods such as read aloud, review, alphabetical methods, and reading comprehension. As one of the recommended methods, read aloud is important to do used for developing literacy activities and increasing the reading literacy of elementary school students. However, not all of teachers know the methods and implementation of read aloud. So, it is necessary to conduct training for teachers to improve competence, insight, and develop literacy activities in primary schools through the use of various literacy reading strategies.

\section{REFERENCES}

Irianto, P.O. \& Febrianti, L.Y. (2017). Pentingnya penguasaan literasi bagi generasi muda dalam menghadapi MEA. The $1^{\text {st }}$ Education and Language International Conference Proceeding, Center for International Language Development of Unissula, pp. 640 - 647. Organisation for Economic Co-operation and Development [OECD]. (2016). PISA 2015 assessment and analytical framework: science, reading mathematic and financial literacy. Paris: OECD Publishing.

Rosidi, A. (2008). Hidup tanpa ijazah, yang terekam dalam kenangan. Jakarta: Pustaka Jaya. Faizah, D.U., Sufyadi, S., Anggraini, L., Waluyo, Dewayani, S., Muldian, W. \& Roosaria, D.R. (2016). Panduan gerakan literasi sekolah di seklah dasar. Jakarta: Direktorat Jenderal Pendidikan Dasar dan Menengah Kementrian Pendidikan dan Kebudayaan.

Setiawan, R. (2017). Membacakan nyaring. Jakarta: Penerbit Noura.

Peraturan Menteri Pendidikan dan Kebudayaan Nomor 23 Tahun 2015 Tentang Penumbuhan Budi Pekerti.

Komalasari, M.D., Wibowo, A., \& Anggraini, D. (2018). Pendampingan gerakan literasi sekolah dalam pembelajaran di sekolah dasar. Jurnal Abdi Masyarakat, 2 (1). 
Journal of Elementary Education

Volume 3, Number 2, September 2019
P-ISSN: 2580-9326

E-ISSN: 2580-7714

Teguh, M. (2017). Aktualisasi kurikulum 2013 di sekolah dasar melalui gerakan literais sekolah untuk menyiapkan generasi unggul dan berbudi pekerti. Prosiding Seminar Nasional, pp. 18 - 28.

Suryono, Harsiati, T., \& Wulandari, I.S. (2017). Implementasi gerakan literasi sekolah pada pembelajaran tematik di sekolah dasar. Sekolah Dasar, 26, (2), 116 - 123.

Tantri, A.A.A. \& Dewantara, I.P.M. (2017). Keefektifan budaya literasi di SDN 3 Banjar Jawa untuk meningkatkan minat baca. Journal of Education Research and Evaluation, 1 (4), pp. $204-209$.

Huda, M., Kartanegara, M., \& Zakaria, G.A.N. (2014) The effect of learning strategy of reading aloud on students' achievement in the subject Islamic studies at secondary school in Semarang. https://www.researchgate.net/publication/273314172 